\title{
PENGARUH CANGKANG KEMIRI SEBAGAI PENGGANTI AGREGAT KASAR TERHADAP SIFAT MEKANIK BETON
}

\section{EFFECT OF CANDLENUT SHELL AS SUBTITUTE COARSE AGGREGATE TO THE MECHANICAL PROPERTIES OF CONCRETE}

\author{
Erniati $^{l_{\pi}}$, Selpedi ${ }^{1}$. Ambo Upe ${ }^{1}$. Erdawaty \\ *email: \\ 'Prodi Teknik Sipil, Fakultas Teknik, Universitas Fajar, Jl. Prof. Abdurrahman Basalamah \\ no. I01, Makassar, 90231
}

\begin{abstract}
ABSTRAK
Teknologi konstruksi beton diarahkan bersifat berkelanjutan dan ramah lingkungan. Limbah cangkang kemiri sebagai pengganti agregat kasar campuran beton diketahui bahwa cangkang kemiri memiliki tekstur yang keras sehingga kemungkinan dapat digunakan sebagai pengganti agregat kasar. Tujuan penelitian ini adalah untuk mengetahui pengaruh limbah cangkang kemiri sebagai pengganti agregat kasar terhadap sifat fisik (slump test, bleeding, segregation, berat isi) dan sifat mekanik (kuat tekan dan kuat tarik belah) beton yang menggunakan cangkang kemiri sebagai material pengganti agregat kasar. Variasi penelitian adalah variasi persentase cangkag kemiri pada campuran beton yakni sebesar $0 \%, 25 \%$, $50 \%, 75 \%$ dan $100 \%$ terhadap volume agregat kasar pada campuran beton. Jumlah benda uji masingmasing 5 buah setiap variasi. Pengujian sifat mekanik beton (kuat tekan dan kuat tarik belah) dilakukan pada umur 28 hari. untuk uji kuat tekan beton, dan 28 hari untuk kuat tarik belah beton serta berat isi beton. Beton yang menggunakan cangkang kemiri sebagai pengganti agregat kasar mengalami penurunan kuat tekan pada sampel BC-25, BC-50, BC-75, BC-100 berturut-turut sebesar $11,72 \mathrm{MPa}(37,71 \%)$; $15,54 \mathrm{MPa}(50,00 \%) ; 18,35 \mathrm{MPa}(59,02 \%) ;$ dan $18,85 \mathrm{MPa}(60,66 \%)$ dari kuat tekan $\mathrm{BN}$ sebesar 31,08 Mpa. Beton yang menggunakan cangkang kemiri sebagai pengganti agregat kasar mengalami penurunan kuat tarik belah pada sampel $\mathrm{BC}-25, \mathrm{BC}-50, \mathrm{BC}-75, \mathrm{BC}-100$ berturut-turut sebesar $0,95 \mathrm{MPa}(28,70 \%)$; $1,21 \mathrm{MPa}(36,56 \%) ; 1,27 \mathrm{MPa}(38,37 \%)$; dan $1,40 \mathrm{MPa}(42,30 \%)$ dari kuat tarik belah BN sebesar 3,31 $\mathrm{MPa}$. Menurunnya nilai berat isi, kuat tekan dan kuat tarik belah sangat dipengaruhi oleh bertambahnya persentase cangkang kemiri pada beton.

Keywods: Concrete, Candlenut shell, Coarse Aggregate, Kuat Tekan, Kuat Tarik Belah
\end{abstract}

\section{ABSTRACT}

Concrete construction technology is directed to be sustainable and ecofriendly. The waste of the candlemut shell as a substitute for the coarse aggregate of concrete mixture is known that the candlenut shell has a hard texture so it may be used as a substitute for coarse aggregates in concrete. The purpose of the research was to determine the effect of Candlemut shell as a substitute of coarse aggregate on physical properties (slump test, bleeding, segregation, volume weight) and mechanical properties (compressive strength and tensile strength) of concrete using Candlemut shell as replacement material of the coarse aggregate. The variation of the research was percentage of the Candlenut shell in the concrete mixture, that was $0 \%, 25 \%, 50 \%, 75 \%$ and $100 \%$ to the coarse aggregate volume in the concrete mixture. Number of specimens in reseach was each 5 pieces each variation. Testing of mechanical properties of concrefe (compressive strength and tensile strength) was performed at 28 days. Testing of the concrefe for compressive strength test and tensile strength on age 28 days. Concrete using candlemut shell as a substitute of coarse aggregates has decreased compressive strength respectively $11.72 \mathrm{MPa}(37.71 \%$ ) for $25 \%$ candlemut shell; $15.54 \mathrm{MPa}(50.00 \%)$ for $50 \%$ candlenut shell; $18.35 \mathrm{MPa}(59.02 \%$ ) for $75 \%$ candlenut shell; And 18,85 MPa $(60,66 \%)$ for $100 \%$ candlenut shell from of the $0 \%$ candlemut shell with compressive strength of $31.08 \mathrm{Mpa}$. Concrete using for $25 \%$ candlenut shell as a substitute for coarse aggregates decreased tensile strength respectively of $0.95 \mathrm{MPa}$ (28.70\%) for $25 \%$ candlemut shell; $1.21 \mathrm{MPa}(36.56 \%)$ for $50 \%$ candlemut shell; $1.27 \mathrm{MPa}(38.37 \%)$ for $75 \%$ candlemut shell; And $1.40 \mathrm{MPa}(42.30 \%$ ) for $100 \%$ candlemit shell from of the $0 \%$ candlemut shell with the tensile strength of $B N$ of $3.31 \mathrm{MPa}$. The decrease in the value of compressive strength and tensile strength is strongly influenced by the increasing percentage of Candlemut shells on concrete.

Keywods:: Concrete, Candlenut shell, Coarse Aggregate, Compressive Strength, Splitting Tensile Strength 


\section{PENDAHULUAN}

Perkembangan Ilmu Pengetahuan dan Teknologi (IPTEK) semakin maju dimana memberikan pengaruh besar bagi seluruh aspek kehidupan. Salah satunya dalam bidang teknik sipil terutama dalam hal teknologi konstruksi, dapat dilihat seperti gedung-gedung bertingkat, jalan, jembatan, Bandar udara, bangunan lepas pantai, stadion, dan lain-lain termasuk pembuatan konstruksi patung. Salah satu material yang paling diminati sekarang ini adalah beton.

Beton merupakan campuran dari bahan penyusunnya yang terdiri dari semen, agregat kasar, agregat halus, air dengan atau tanpa bahan tambah. Beton yang berkualitas jika beton mempunyai sifat mekanik dan ketahanannya yang baik. Sifat mekanik beton yang paling penting adalah kuat tekan. Karakteristik kekuatan beton sangat berhubungan dengan karakteristik lainnya seperti mikrostruktur dan porositas beton, (Erniati \& M. Wihardi Tjaronge, 2016). Mikrostruktur dan porositas beton mempengaruhi dengan kata lain jika kuat tekannya tinggi maka karakteristik lainnya juga baik, (Erniati dkk, 2015).

Winter dan Nilon, 1993, membedakan tiga kelompok beton ringan yakni 1). Beton dengan berat jenis rendah, yang terutama dipakai sebagai isolasi dengan berat isi kurang dari $800 \mathrm{~kg} / \mathrm{m} 3$; 2). Beton berkekuatan menegah, dengan berat isi berkisar antara $960-1360 \mathrm{~kg} / \mathrm{m} 3 \quad$ dan berkekuatan tekan antara 6,89-17,23 MPa) yang terutama dipakai sebagai pengisi, misalnya pada panel-panel lantai baja berukuran ringan; 3) Beton struktur, dengan berat isi berkisar antara $1440-1920 \mathrm{~kg} / \mathrm{m} 3$ dengan kekuatan tekan yang sama besarnya dengan kekuatan beton biasa. Beton ringan struktural adalah beton yang memakai agregat ringan atau campuran agregat kasar ringan dan pasir alam sebagai pengganti agregat halus ringan dengan ketentuan tidak boleh melampaui berat isi maksimum beton 1850 $\mathrm{kg} / \mathrm{m} 3$ dan harus memenuhi ketentuan kuat tekan dan kuat tarik belah beton ringan untuk tujuan struktural, (SNI 03-3449-1994).

Kandungan agregat dalam campuran beton sangat tinggi, yaitu berkisar $60 \%-70 \%$ dari berat campuran beton. Agregat adalah sekumpulan butir-butir batu pecah, kerikil, pasir, atau mineral lainnya baik berupa hasil alam maupun buatan yang berfungsi sebagai bahan pengisi dalam campuran mortar dan beton. Walaupun fungsinya hanya sebagai pengisi, tetapi karena komposisinya yang cukup besar agregat ini menjadi sangat penting, (Tri Mulyono, 2004).

Kebutuhan agregat dalam pembuatan beton sangat tinggi, sehingga menyebabkan pengurangan jumlah sumber alam yang tersedia untuk keperluan struktur beton, disamping itu merusak lingkungan. Alternatif yang dapat digunakan untuk mengatasi masalah tersebut dengan memanfaatkan limbah-limbah sekitar lingkungan sebagai bahan tambah atau pengganti agregat.

Indonesia adalah Negara yang memiliki sumber daya alam pertanian yang tinggi. oleh karena itu perlu mencari inovasi baru untuk campuran beton dengan menggunakan hasil pertanian yang sudah tidak dimanfaatkan lagi berupah limbah seperti limbah tempurung kelapa dan limbah cangkang kemiri. Salah satu penghasil kemiri di Indonesia adalah provinsi sulawesi selatan tepatnya di daerah Maros, barru, bantaeng, soppeng luwu dan wajo Penelitian sebelumnya I Wayan Suarnita 2010, tempurung kelapa sebagai pengganti agregat dalam beton, dengan hasil nilai berat isi rata-rata yaitu 1.701 $\mathrm{kg} / \mathrm{m} 3$, nilai kuat tekan rata-rata yaitu 14,054 MPa. Hal inilah yang mendorong untuk meneliti beton yang berkelajutan dan ramah lingkungan dengan memanfaatkan limbah cangkang kemiri untuk mengganti agregat dalam beton.

\section{METODE PENELITIAN}

Metode yang digunakan dalam penelitian ini adalah metede eksperimental yang dilaksanakan di laboratorium. Pemeriksaan karakteristik agregat kasar dan agregat halus, pembuatan sampel beton dan pengujian mekanik beton dilakukan di Laboratorium Bahan dan Beton, Program Teknik Sipil, Fakultas Teknik, Universitas Fajar. 
Adapun bahan, peralatan, desain pencampuran dan ekperimental dijelaskan sebagai berikut :

\section{Bahan dan Peralatan}

Bahan yang digunakan dalam penelitian ini adalah semen tipe Portland Cement Composite (PCC), agregat kasar/batu pecah (ukuran maksimum $20 \mathrm{~mm}$ ), agregat halus/pasir lokal (ukuran maksimum 4,75) dan Cangkang Kemiri.

Peralatan yang digunakan dalam penelitian ini adalah oven, ayakan, mesin los angeles, mesin pencampur bahan (mixer), gelas ukur, cetakan silinder dengan diameter $10 \mathrm{~cm}$ dan tinggi $20 \mathrm{~cm}$, timbangan, Universal Testing Machine (UTM), dan peralatan pendukung lainnya.

\section{Mix Desain dan Ekperimental Prosedur}

Pemeriksaan karakteristik agregat kasar dan agregat halus dilakukan terlebih dahulu sebelum menghitung mix desain beton dengan berdasarkan standar ASTM. Metode yang digunakan dalam desain Beton adalah metode Development of Environment (DOE). Faktor air semen yang digunakan adalah 0,48 .

Benda uji dibuat dengan variasi campuran dengan $0 \%, 25 \%, 50 \%, 75 \%$ dan $100 \%$ cangkang kemiri dari jumlah agregat kasar. Masing-masing sampel dibuat 10 buah /variasi campuran dimana 5 buah untuk pengujian kuat tekan dan 5 buah untuk pengujian kuat tarik belah. Jadi Jumlah sampel keseluruhan 50 buah sampel. Sampel dibuat dengan menggunakan cetakan silinder ukuran $10 \mathrm{~mm}$ x $20 \mathrm{~mm}$. Untuk setiap variasi sampel diberi nama yakni untuk $0 \%$ cangkang kemiri $=\mathrm{BN}, 25 \%$ cangkang kemiri $=$ BC-25, 50\% cangkang kemiri $=$ BC-50, 75\% cangkang kemiri $=\mathrm{BC}-75,100 \%$ cangkang kemiri $=\mathrm{BC}-100$.

Hasil mix design dilakukan pencampuran dengan menggunakan alat mixer. Sebelum beton dituang dalam cetakan silinder (dalam kondisi beton segar), terlebih dahulu dilakukan pengujian sifat fisik beton segar yakni slump test, bleeding, segregasi dan berat volume beton. Setelah 24 jam benda uji dibuat, benda uji dilepas dari cetakan kemudian dilakukan perawatan beton dirawat dengan cara sampel beton direndam dalam bak air selama 28 hari. Setelah itu dikeluarkan dari bak air kemudian di diamkan kurang lebih 20 jam berdasarkan SNI 03-2493 sebelum dilakukan pengujian kuat tekan dan kuat tarik belah. Pengujian mekanik yang dilakukan adalah kuat tekan berdasarkan ASTM C39/C39M -12a dan kuat tarik belah berdasarkan ASTM C496/C496M-11. Pengujian kuat tekan dan kuat tarik belah dilakukan pada umur 28 hari masingmasing 5 sampel setiap variasi campuran.

\section{HASIL DAN PEMBAHASAN \\ Agregat}

Pengujian Agregat baik agregat halus dan agregat kasar dilakukan dilaboratorium berdasarkan standar SNI. Hasil pengujian material agregat diperoleh karakteristik agregat halus dan agregat kasar telah memenuhi kriteria sebagai material penyusun beton. Hasil pengujian agregat halus dan agregat kasar dapat dilihat berturut-turut pada Tabel 1 dan Tabel 2 . 
Tabel 1. Hasil Pemeriksaan Karakteristik Agregat Halus (Pasir)

\begin{tabular}{|l|l|l|l|l|}
\hline $\begin{array}{l}\text { N } \\
\mathbf{0}\end{array}$ & $\begin{array}{l}\text { Karakteristik } \\
\text { Agregat }\end{array}$ & SNI & $\begin{array}{l}\text { Hasil } \\
\text { Pemeriksaa } \\
\text { n }\end{array}$ & Keterangan \\
\hline 1 & Analisa Saringan & $\begin{array}{l}\text { Gradasi } \\
\text { Zona 2 }\end{array}$ & Memenuhi \\
\hline 2 & Modulus Kehalusan & $2,3-3,1$ & 2,77 & Memenuhi \\
\hline & $\begin{array}{l}\text { Berat Jenis : } \\
\text { a. BJ Nyata } \\
\text { b. BJ Dasar Kering } \\
\text { c. BJ Kering } \\
\text { Permukaan }\end{array}$ & $\begin{array}{l}1,6-3,30 \\
1,6-3,31\end{array}$ & $\begin{array}{l}2,58 \\
2,45\end{array}$ & $\begin{array}{l}\text { Memenuhi } \\
\text { Memenuhi } \\
\text { Memenuhi }\end{array}$ \\
\hline 4 & Absorpsi & $0,2-2 \%$ & 1,04 & Memenuhi \\
\hline & $\begin{array}{l}\text { Berat Volume : } \\
\text { a. Kondisi Lepas } \\
\text { b. Kondisi Padat }\end{array}$ & $\begin{array}{l}1,4-1,9 \\
\mathrm{~kg} / \mathrm{ltr} \\
1,4-1,9 \\
\mathrm{~kg} / \mathrm{ltr}\end{array}$ & $\begin{array}{l}1,41 \\
1,60\end{array}$ & $\begin{array}{l}\text { Memenuhi } \\
\text { Memenuhi }\end{array}$ \\
\hline 6 & Kadar Air & $3 \%-5 \%$ & $4,71 \%$ & Memenuhi \\
\hline 7 & Kadar Lumpur & $\begin{array}{l}\text { Maks } 0,2- \\
5 \%\end{array}$ & $4,5 \%$ & Memenuhi \\
\hline 8 & Kadar Organik & $<$ No. 3 & No. 2 & Memenuhi \\
\hline
\end{tabular}

Tabel 2. Hasil Pemeriksaan Karakteristik Agregat Kasar (Batu Pecah)

\begin{tabular}{|c|c|c|c|c|}
\hline No. & $\begin{array}{l}\text { Karakteristik } \\
\text { Agregat }\end{array}$ & SNI & $\begin{array}{l}\text { Hasil } \\
\text { Pemeriksaa } \\
\text { n }\end{array}$ & Keterangan \\
\hline 1 & Analisa Saringan & & $\begin{array}{l}\text { Gradasi } \\
\text { zone } 2\end{array}$ & Memenuhi \\
\hline 2 & Modulus Kehalusan & $6-7,1$ & 6,64 & Memenuhi \\
\hline 3 & $\begin{array}{l}\text { Berat Jenis : } \\
\text { a. } \text { BJ Nyata } \\
\text { b. BJ Dasar kering } \\
\text { c. BJ Kering } \\
\text { Permukaan }\end{array}$ & $\begin{array}{lr}1,6 & - \\
3,33 & \\
1,6 & - \\
3,33 & \\
1,6 & - \\
3,33 & \end{array}$ & $\begin{array}{l}2,85 \\
2,73 \\
2,77\end{array}$ & $\begin{array}{l}\text { Memenuhi } \\
\text { Memenuhi } \\
\text { Memenuhi }\end{array}$ \\
\hline 4 & Absorpsi & maks $4 \%$ & $1,56 \%$ & Memenuhi \\
\hline 5 & $\begin{array}{l}\text { Berat Volume : } \\
\text { a. Kondisi Lepas } \\
\text { b. Kondisi Padat }\end{array}$ & $\begin{array}{l}1,6-1,9 \\
\mathrm{~kg} / \mathrm{ltr} \\
1,6-1,9 \\
\mathrm{~kg} / \mathrm{ltr}\end{array}$ & $\begin{array}{l}1,66 \\
1,74\end{array}$ & $\begin{array}{l}\text { Memenuhi } \\
\text { Memenuhi }\end{array}$ \\
\hline 6 & Kadar Air & $\begin{array}{l}0,5 \%-2 \\
\%\end{array}$ & $1,78 \%$ & Memenuhi \\
\hline 7 & Kadar Lumpur & maks $1 \%$ & 0,75 & Memenuhi \\
\hline 8 & Keausan & $\begin{array}{l}\text { maks } \\
50 \%\end{array}$ & $30,45 \%$ & Memenuhi \\
\hline
\end{tabular}




\section{Slump Test, Bleeding dan segregasi}

Pengukuran Slump test dilakukan untuk mengetahui kelecakan (workability) adukan beton. Kelecakan adukan beton merupakan ukuran dari tingkat kemudahan campuran untuk diaduk, diangkut, dituang dan dipadatkan tanpa menimbulkan pemisahan kerikil (segregation) serta naiknya air kepermukaan (bleeding). Tingkat kelecakan ini dipengaruhi oleh komposisi campuran, kondisi fisik dan jenis bahan pencampurnya. Hasil pengujian slump test dapat dilihat pada Tabel 3.

Tabel 3. Hasil Pengukuran Nilai Slump

\begin{tabular}{|l|l|l|l|l|}
\hline No & $\begin{array}{l}\text { Nama } \\
\text { Sampel }\end{array}$ & $\begin{array}{l}\text { Slump } \\
\text { Test 1 } \\
(\mathbf{c m})\end{array}$ & $\begin{array}{l}\text { Slump } \\
\text { Test 2 } \\
\text { (cm) }\end{array}$ & $\begin{array}{l}\text { Nilai } \\
\text { rata- } \\
\text { rata } \\
\text { (cm) }\end{array}$ \\
\hline 1 & BN & 10,7 & 11,3 & 11 \\
\hline 2 & BC -25 & 11,7 & 11,5 & 11,6 \\
\hline 3 & BC -50 & 11,9 & 12,1 & 12 \\
\hline 4 & BC -75 & 12,1 & 12,9 & 12,5 \\
\hline 5 & BC -100 & 12,5 & 13,1 & 12,8 \\
\hline
\end{tabular}

Dari Tabel 3 dapat dilihat bahwa nilai slump untuk beton normal maupun beton dengan campuran cangkang kemiri memenuhi syarat standar slump yakni $6-18 \mathrm{~cm}$. Itu adukan beton memiliki workability yang baik, dengan kata lain bahwa kemudahan dalam pencampuran sangat baik dan mudah. Dari hasil pengujian slump test ini juga menunjukkan adukan campuran beton telah tercampur dengan merata dan sempurna dan terlihat tidak terjadi segregasi (pemisahan kerikil) dan bleeding (naiknya air kepermukaan) pada adukan beton segar.

\section{Berat Volume Beton}

Pemeriksaan bearat satuan beton dilakukan pada saat beton berumur 28 hari. Adapun hasil pengujian rata-rata berat volume beton dapat dilihat pada Tabel 4.

Tabel 4 berikut, menampilkan hasil pengujian berat volume beton dengan berbagai variasi campuran cangkang kemiri, dimana reduksi terlihat bahwa semakin tinggi persentase cangkang kemiri semakin tinggi reduksinya terhadap berat volume.
Tabel 4. Hasil pengujian berat volume beton

\begin{tabular}{|l|l|l|}
\hline $\begin{array}{l}\text { Persentase } \\
\text { Cangkang } \\
\text { Kemiri (\%) }\end{array}$ & $\begin{array}{l}\text { Nilai rata } \\
\text { ratarat berat } \\
\text { volume beton } \\
\left(\mathbf{k g} / \mathbf{m}^{3}\right)\end{array}$ & $\begin{array}{l}\text { Reduksi } \\
(\%)\end{array}$ \\
\hline 0 & 2435,03 & 0 \\
\hline 25 & 2275,67 & 6,54 \\
\hline 50 & 2193,95 & 9,90 \\
\hline 75 & 2078,34 & 14,65 \\
\hline 100 & 1987,26 & 18,39 \\
\hline
\end{tabular}

Dari hasil pengujian berat volume yang $100 \%$ cangkang kemiri mendekati persyaratan beton ringan namun demikian masih belum memenuhi syarat beton ringan yakni 1987,26>1900 kg/m3 (Winter, G. dan Nilson, A.H., 1993).

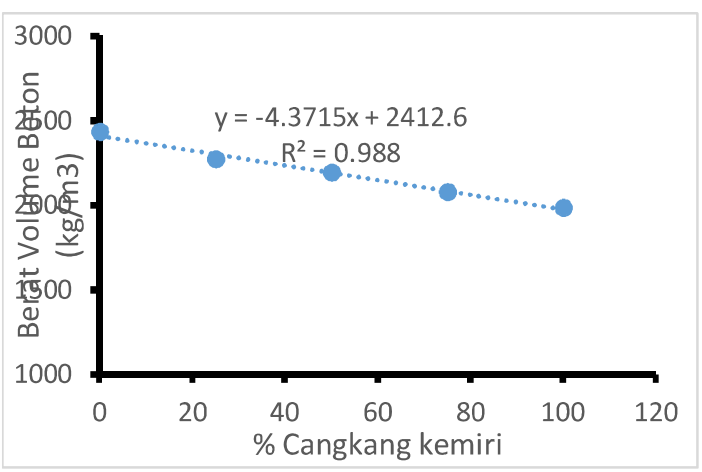

Gambar 1. Hubungan antara berat volume beton dengan persentase penambahan cangkang kemiri.

Gambar 1 menunjukkan regresi linier hubungan antara volume beton dengan persentase penambahan cangkang kemiri sebagai pengganti agregat kasar, dimana semakin tinggi persentase cangkang kemiri maka semakin rendah berat volume. Hubungan berat volume dan persentase cangkang kemiri menghasilkan persamaan hasil linear $\mathrm{y}=-4,371 \mathrm{X}+241,6$ dengan nilai koefisien determinasi $\mathrm{R}^{2}=0,988$ maka disimpulkan bahwa persentase cangkang kemiri sangat mempengaruhi berat volume beton.

\section{Kuat Tekan dan Kuat Tarik Belah}

Kekuatan beton dapat dinilai dengan melihat sifat mekaniknya terutama kuat tekan. Kuat tekan beton merupakan besarnya beban maksimal (beton hancur) per satuan luas. Penyebab benda uji beton hancur jika dibebani dengan gaya tekan 
tertentu yang dihasilkan oleh mesin tekan. kuat tekan beton ditentukan oleh pengaturan dari perbandingan semen, agregat kasar dan halus, air dan berbagai zat tambah campuran. Faktor air semen merupakan faktor utama dalam menentukan kekuatan beton. Semakin rendah faktor air semen, semakin tinggi kuat tekan beton. Namun kelebihan air meningkatkan kemampuan kemudahan dalam pengerjaan beton (workability) akan tetapi menurunkan kekuatan.

Selain kuat tekan, uji kuat tarik belah juga sangat penting dilakukan. Metode uji belah silinder (spliting tensile strength) yang umumnya memberikan hasil yang lebih baik dan lebih mencerminkan kuat tarik sebenarnya. Nilai pendekatan yang diperoleh dari hasil pengujian berulang kali kuat tarik $\mathrm{T}=0,50-0,60 \sqrt{f^{\prime} c}$ (Istimawan D, 1994). Pasal 11.5 SNI-03-2847 (2002) nilai kuat tarik beton bila dihubungkan dengan kuat tekannya adalah $\mathrm{T}=0,7 \sqrt{f^{\prime} c}(\mathrm{MPa})$. Pengujian kuat tekan dan kuat tarik belah beton pada umur 28 dapat dilihat berturut-turut pada Tabel 4 dan Tabel 5.

Tabel 4 memperlihatkan hasil nilai rata-rata kuat tekan beton normal $\mathrm{BN}$ sebagai pembanding (Blangko) diperoleh kuat tekan sebesar 31,08 MPa. Pada penelitian ini sesuai nilai kuat tekan pada beton dengan $0 \%$ cangkang kemiri sesuai target yang direncanakan. Namun untuk beton yang menggunakan cangkang kemiri sebagai pengganti agregat kasar mengalami penurunan kuat tekan pada sampel BC-25, BC-50, BC-75, BC-100 berturut-turut sebesar 11,72 $\mathrm{MPa}(37,71 \%) ; 15,54$ MPa (50,00\%); 18,35 MPa (59,02\%); dan 18,85 MPa (60,66\%). dari kuat tekan BN sebesar 31,08 Mpa.

Tabel 4. Hasil Pengujian Kuat tekan dan Kuat Tarik Belah

\begin{tabular}{|l|l|l|l|}
\hline \multirow{2}{*}{ No } & \multirow{2}{*}{$\begin{array}{l}\text { Nama } \\
\text { Sampel }\end{array}$} & \multicolumn{2}{|l|}{ Nilai rata-rata $($ Mpa) } \\
\cline { 3 - 4 } & & $\begin{array}{l}\text { Kuat } \\
\text { Tekan }\end{array}$ & $\begin{array}{l}\text { Kuat Tarik } \\
\text { Belah }\end{array}$ \\
\hline 1 & BN & 31,08 & 3,31 \\
\hline 2 & BC-25 & 19,36 & 2,36 \\
\hline 3 & BC-50 & 15,54 & 2,10 \\
\hline 4 & BC-75 & 12,74 & 2,04 \\
\hline 5 & BC-100 & 12,23 & 1,91 \\
\hline
\end{tabular}

Tabel 4 juga memperlihatkan hasil nilai ratarata kuat tarik belah BN sebagai pembanding (Blangko) diperoleh kuat tarik belah sebesar 3,31 $\mathrm{MPa}$. Beton yang menggunakan cangkang kemiri sebagai pengganti agregat kasar mengalami penurunan kuat tarik belah pada sampel BC-25, BC-50, BC-75, BC-100 berturut-turut sebesar 0,95 $\mathrm{MPa}(28,70 \%) ; 1,21 \mathrm{MPa}(36,56 \%) ; 1,27 \mathrm{MPa}$ (38,37\%); dan 1,40 MPa $(42,30 \%)$ dari kuat tarik belah BN sebesar 3,31 Mpa.

Nilai kuat tekan variasi $100 \%$ mendapatkan nilai kuat tekan 12,23 MPa yang dapat digunakan sebagai campuran beton untuk rabat beton pejalan kaki dan pembuatan taman yang nilai kuat tekan yang disyaratkan yaitu $10 \mathrm{MPa}$ dimana kita dapat lihat dengan variasi $100 \%$ cangkang kemiri dengan hasil kaut tekan melebihi yang disyaratkan. Dengan demikian untuk $100 \%$ cangkang kemiri mengganti aggregat kasar dapat digunakan untuk rabat beton pejalan kaki dan taman.

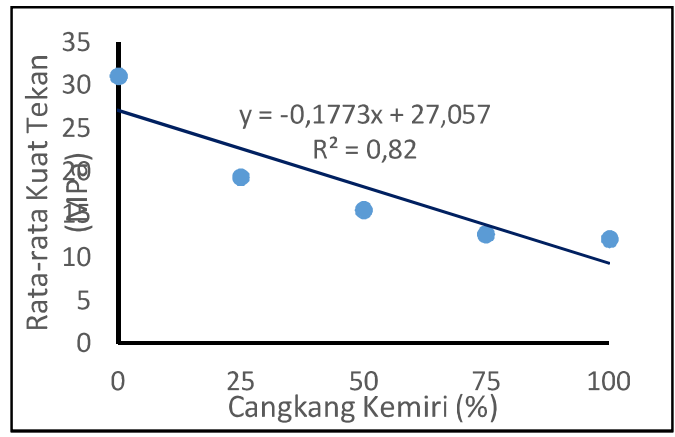

Gambar 2. Hubungan kuat tekan dengan persentase cangkang kemiri dalam beton

Gambar 2 menggambarkan regresi linier hubungan hasil kuat tekan beton dengan persentase penambahan cangkang kemiri sebagai pengganti agregat kasar, dimana terlihat semakin tinggi persentase cangkang kemiri maka semakin rendah kuat tekannya. Hal ini terlihat hasil hubungan kuat tekan dan persentase cangkang kemiri menghasilkan persamaan regresi linear $\mathrm{y}=$ $0.1773 x+27.057$ dengan koefisien determinasi $\mathrm{R}^{2}$ $=0.82$. Dari hasil koefisien determinasi $\mathrm{R}^{2}$ maka disimpulkan bahwa beton dengan persentase cangkang kemiri sangat mempengaruhi kuat tekannya beton. 


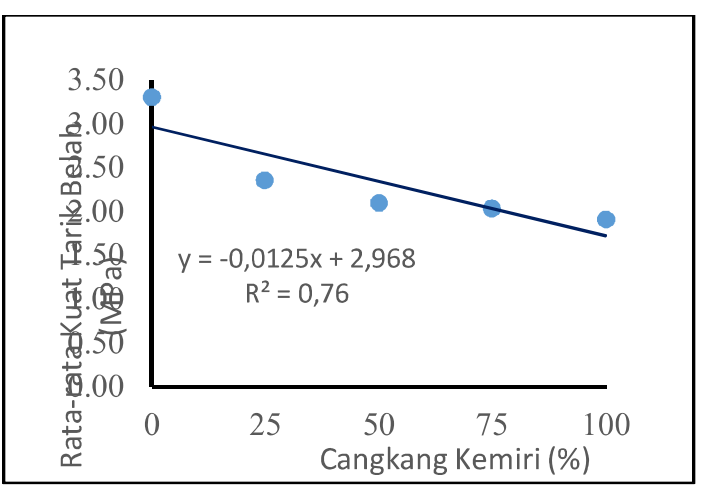

Gambar 3. Hubungan kuat tarik belah dengan \% cangkang kemiri dalam beton

Gambar 3 menggambarkan regresi linier hubungan hasil kuat tarik belah beton dengan persentase penambahan cangkang kemiri sebagai pengganti agregat kasar, dimana terlihat semakin tinggi persentase cangkang kemiri maka semakin rendah kuat tarik belahnya. Hal ini terlihat hasil hubungan kuat tarik belah dan persentase cangkang kemiri menghasilkan persamaan regresi linear $\mathrm{y}=-0,0125 \mathrm{x}+2,968$ dengan koefisien determinasi $\mathrm{R}^{2}=0.76$. Dar hasil koefisien determinasi $\mathrm{R}^{2}$ maka disimpulkan bahwa beton dengan persentase cangkang kemiri sangat mempengaruhi kuat tarik belah beton.

Penambahan $25 \%$ dan $50 \%$ cangkang kemiri dari volume pengganti agregat kasar dapat dikategorikan sebagai beton mutu rendah kelas a, dengan nilai kuat tekan 19,36 MPa dan 15,54 MPa yang dimana disyaratkan $15 \leq 20 \mathrm{MPa}$. Penurunan kuat tekan dan kuat tarik belah sangat dipengaruhi bertambahnya persentase cangkang kemiri pada beton. Penurunan kuat tekan dan kuat tarik belah terjadi pada beton seiring dengan bertambahnya persentase cangkang kemiri sebagai pengganti agregat kasar. Ini disebabkan karena karakteristik cangkang kemiri memiliki banyak perbedaan dengan karakeristik dari agregat kasar, sehingga ikatan matriks dengan cangkang kemiri tidak begitu optimal sehingga mengakibatkan kekuatan dan mikrostruktur pada beton tidak begitu padat. Sebagaimana penelitian sebelumnya tentang mikrostruktur beton memadat sendiri bahwa kekuatan beton dipengaruhi oleh ikatan matriks beton, mikrostruktur dan porositas (Erniati, 2015).

\section{PENUTUP}

\section{Kesimpulan}

Desain pencampuran beton dengan menggunakan semen PCC, batu pecah dengan ukuran maksimum $20 \mathrm{~mm}$, faktor air semen $=0,48$ menghasilkan beton segar dengan slump test memenuhi syarat, sehingga adukan campuran beton segar memiliki workability yang baik, tidak terjadi segregasi (pemisahan kerikil) dan bleeding (naiknya air kepermukaan). Beton yang menggunakan cangkang kemiri sebagai pengganti agregat kasar mengalami penurunan kuat tekan pada sampel BC-25, BC-50, BC-75, BC-100 berturut-turut sebesar 11,72 MPa (37,71\%); 15,54 MPa (50,00\%); 18,35 MPa (59,02\%); dan 18,85 MPa (60,66\%). dari kuat tekan BN sebesar 31,08 Mpa. Beton yang menggunakan cangkang kemiri sebagai pengganti agregat kasar mengalami penurunan kuat tarik belah pada sampel BC-25, BC-50, BC-75, BC-100 berturut-turut sebesar 0,95 MPa (28,70\%); 1,21 MPa (36,56\%); 1,27 MPa (38,37\%); dan 1,40 MPa (42,30\%) dari kuat tarik belah BN sebesar 3,31 Mpa. Menurunya nilai, berat volume, kuat tekan dan kuat tarik belah sangat dipengaruhi oleh bertambahnya persentase cangkang kemiri pada beton.

\section{REFERENSI}

ASTM C39/C39M - 12a, Standard Test Method for Compressive Strength of Cylindrical Concrete Specimens, October 2012.

ASTM C496/C496M-11,2011 Standard Test Method for Splitting Tensile Strength of Cylindrical Concrete Specimen, August 2011.

Dipohusodo Istimawan. 1994. Struktur Beton Betulang, Gramedia

Erniati, M.Wihardi.Tjaronge, Rudy Djamaluddin, Victor Sampebulu. 2015. Compressive Strength and Slump Flow of Self Compactig Concrete Uses Fresh Water and Sea Water, ARPN Journal of Engineering and Applied Sciences: Vol 10. Number 6, pp 2373-2377. 
Erniati, M.Wihardi.Tjaronge, Rudy Djamaluddin, Victor Sampebulu. 2015. Porosity and Microstructure Phase of Self Compacting Concrete Using Sea Water as Mixing Water and Curing, Advanced Material Research, Vol. 1119, pp 647-651.

Erniati, M.Wihardi.Tjaronge, Zulharnah, Ulfa Ria Arvan. 2015. Porosity, pore size and compressive strength of self compacting concrete, Procedia Engineering, Vol 125, pp $832-837$.

Erniati dan M. Wihardi Tjaronge (2016). Mikrostruktur Self Compacting Concrete, Penerbit Leutika, Yogyakarta

I wayan Suarnita, 2010. Karakteristik Beton Ringan Dengan Menggunakan Tempurung kelapa Sebagai Bahan Pengganti Agregat Kasar, Jurnal SMARTek, Vol.8, No.1, Februari $2010: 22-33$

SNI 03-2847-2002. Tata Cara Perhitungan Struktur Beton untuk Bangunan Gedung, Beta version, Bandung.

SNI 03-3449-1994. Beton ringan, Tata cara pembuatan campuran dengan agregat ringan

Tri Mulyono, 2004, Teknologi Beton, edisi I, ANDI, yogyakarta.

1. Winter, G. dan Nilson, A.H., 1993, Perencanaan Beton Bertulang, PT. Pradnya Paramita, Jakarta

\section{DAFTAR PUSTAKA}

Arianto, Tri, Juli 2009," Implementasi Wireless Local Area Network dalam RT/RW Net", Jurnal Teknologi Informasi DINAMIK Volume XIV, No.2, 152-157

Borg \& Gall, 1979. Educational Research: an introduction. New York: Longman, Inc. Februariyanti, Herny, Juli 2008," Internert Murah dengan Membangun Jaringan RT/RW-NET”, Jurnal Teknologi Informasi DINAMIK Volume XIII, No.2, : 98-114
Laksamana,Teguh,April 2016,"'Implementasi Kampung Wifi RT/RW-NET Sebagai Solusi Internet Murah Indonesia Dengan Inovasi Antena Penguat Sinyal Wifi 2.4 Ghz". Jakarta

Pamungkas, Probo, 2013,” Dasar Kerja Mikrotik Dan Fungsinya".Semarang.

Suryanti, Dika, Februari 2010,"Membangun Jaringan Rt Rw Net Sebagai Solusi Internet Murah".Sriwijaya 